Dinamika Sosial Budaya, Vol 22, No. 1, Juni 2020, pp 54-64

p-ISSN: 1410-9859\& e-ISSN: 2580-8524

http://journals.usm.ac.id/index.php/jdsb

\title{
KESALAHAN GRAMATIKAL PADA TEKS TERJEMAHAN ABSTRAK (INDONESIA- INGGRIS) MAHASISWA UNIVERSITAS SEMARANG (USM)
}

\author{
Stefani Dewi Rosaria \\ stefani@usm.ac.id \\ Fakultas Hukum, Universitas Semarang \\ Devy Angga Gunantar \\ angga.gunantar@gmail.com \\ Fakultas Teknologi Hasil Pertanian, Universitas Semarang \\ Adiprana Yogatama \\ adiprana.linguist@gmail.com \\ Fakultas Psikologi, Universitas Semarang
}

\begin{abstract}
Abstrak
Penelitian ini merupakan penelitian deskriptif kualitatif yang bertujuan untuk mendeskripsikan jenis kesalahan gramatikal yang terdapat pada teks terjemahan (Indonesia-Inggris) para mahasiswa Universitas Semarang. Hasil penelitian ini menunjukkan bahwa dari 366 kalimat yang diteliti terdapat 547 kesalahan gramatikal pada teks abstrak para mahasiswa. Kesalahan terbanyak adalah pada penghilangan kata sandang atau article yaitu sebanyak 189 kesalahan. Ketidaksesuaian antara subjek dan kata kerja menjadi jenis kesalahan kedua yang sering terjadi dan pembentukan kalimat yang tidak lengkap menjadi jenis kesalahan terbanyak ketiga. Berdasarkan temuan tersebut dapat disimpulkan bahwa pemahaman para mahasiswa dalam menerjemahkan teks masih kurang karena mengabaikan struktur kalimat bahasa sasaran yang baik dan benar.
\end{abstract}

Kata Kunci: kesalahan gramatikal; abstrak; terjemahan

\begin{abstract}
This is a descriptive qualitative research which aims to describe a grammatical error in translated abstract texts (Indonesia-English) written by students of Semarang University. The result showed that there were 366 sentences containing 547 grammatical errors made by the students. The most grammatical errors made by the students are the omission of article with 189 errors. Following the omission of article was the subject and verb agreement and the third most errors occurred was the sentence fragment. It can be concluded that the students' understanding in translating the text is lack and they are ignoring the sentence structure of the target language.
\end{abstract}

Keywords: grammatical errors; abstract; translation

\section{PENDAHULUAN}

Abstrak menjadi bagian penting yang wajib ada dalam setiap penulisan karya ilmiah seperti skripsi, tesis ataupun jurnal. Di dalam abstrak tersebut dijelaskan isi tulisan secara ringkas. Jika pembaca ingin mengetahui isi sebuah karya ilmiah, sebagai langkah awal mereka dapat membaca abstraknya terlebih dahulu untuk mendapatkan gambaran mengenai isinya.

Abstrak ditulis secara ringkas meliputi latar belakang, permasalahan, metode dan temuan atau hasilpenelitian. Singkatnya, abstrak menjadi gambaran umum tentang isi suatu karya ilmiah, memberikan informasi yang singkat dan padat namun mencakup keseluruhan isi suatu karya ilmiah. 
Sebagai salah satu syarat yang harus ditempuh oleh para mahasiswa agar dapat memperoleh gelar sarjananya adalah dengan menulis sebuah karya ilmiah, skripsi atau tesis sebagai tugas akhir. Di dalam tesis atau skripsi tersebut tentu saja para mahasiswa harus menuliskan abstrak baik dalam bahasa Indonesia maupun dalam bahasa Inggris. Proses menulis abstrak dalam bahasa Inggris biasanya dengan menerjemahkan teks abstrak dari bahasa Indonesia. Masalah yang kemudian muncul adalah menerjemahkan tidak semata-mata mengubah tulisan ke dalam bahasa Inggris, namun melibatkan ketrampilan atau skill yang sebenarnya tidak mudah. Untuk dapat diterjemahkan, pertama-tama teks berbahasa Indonesia haruslah jelas dan benar tata bahasanya. Jika pada teks berbahasa Indonesia sudah baik dan berterima maka proses menerjemahkan ke bahasa Inggris juga akan mudah. Ketika menerjemahkan teks, paling tidak seseorang harus memiliki pengetahuan dasar tata bahasa bahasa sasaran, mengetahui dan memperhatikan tata bahasa bahasa sasaran karena pasti berbeda dengan tata bahasa bahasa sumber. Masalahnya banyak diantara para mahasiswa yang kurang memperhatikan persoalan tersebut. Yang mereka pikirkan adalah terlepas dari benar atau salah para mahasiswa sudah menuliskan atau menerjemahkan abstrak mereka ke dalam bahasa Inggris. Terlebih tidak semua mahasiswa memiliki pengetahuan yang baik mengenai penerjemahan karena bidang yang mereka pelajari bukan bahasa Inggris, sehingga seringkali terjadi kesalahan dalam menerjemahkan teks berbahasa Indonesia ke dalam bahasa Inggris.

Berdasarkan uraian tersebut, penelitian ini bertujuan untuk mendeskripsikan kesalahan-kesalahan gramatikal yang seringkali terjadi pada teks abstrak bahasa Inggris yang diterjemahkan dari bahasa Indonesia. Nantinya temuan dari penelitian ini dapat dijadikan sumber informasi atau rujukan dalam hal penerjemahan teks.

Menerjemahkan bukanlah suatu hal yang mudah karena pengetahuan penerjemah tentang bahasa sasaran harus baik dan benar. Jika penerjemahan dilakukan secara asalasalan, teks terjemahan yang dihasilkan sseringkali tidak bisa dimengerti oleh pembaca karena dapat dipastikan ada kekeliruan atau kesalahan dalam merangkai kalimat. Catford
(1965:20) mendefinisikan penerjemahan sebagai penempatan teks bahasa sumber dengan teks yang sepadan dalam bahasa sasaran. Sehingga penerjemahan bukanlah hal yang mudah dan sederhana tetapi kompleks karena tidak terlepas dari berbagai faktor yang terkait dengan linguistik, yaitu faktor budaya (Hatim, 2001: 10).

\section{Larson (1989:3) mengemukakan} bahwa penerjemahan sebagai pengalihan makna dari bahasa sumber ke dalam bahasa sasaran, pengalihan ini dilakukan dari bentuk bahasa pertama ke dalam bentuk bahasa kedua melalui struktur semantik.

Menurut Nababan proses penerjemahan adalah serangkaian kegiatan yang dilakukan dengan sengaja. Proses penerjemahan dapat diartikan pula sebagai serangkaian kegiatan yang dilakukan oleh seorang penerjemah pada saat ia mengalihkan amanat dari bahasa sumber ke bahasa sasaran. Tentu saja pengalihan amanat ini juga harus didasari oleh berbagai kemampuan yang wajib dimiliki oleh seorang penerjemah, misalnya kebahasaan, pengusaan teknik, teori, penggunaan sarana pembantu, dan lainnya (2003:25).

Pengertian penerjemahan menurut Nida dan Taber dalam Suryawinata (2003:13) yaitu usaha mencipta kembali pesan yang ada dalam bahasa sumber ke dalam bahasa sasaran dengan menggunakan padanan alami yang paling dekat. Paling dekat dalam hal makna terlebih dahulu kemudian baru gaya bahasanya.

Berdasarkan uraian yang dipaparkan oleh para ahli tersebut, dapat ditarik simpulan bahwa proses penerjemahan adalah proses yang kompleks karena berkenaan dengan berbagai faktor, seperti faktor budaya, kebahasaan, kealamiannya dan keberterimaannya. Menerjemahkan tidak hanya mengubah bahasa saja dari bahasa sumber ke bahasa sasaran tetapi juga harus mempertimbangkan pilihan-pilihan kata yang berterima secara alami ke dalam bahasa sasaran. Oleh karena itu seorang penerjemah harus memperhatika prinsip penerjemahan dengan baik. Menurut Basnet (2005:61) prinsip penerjemahan adalah sebagai berikut: (1) penerjemah harus memahami makna dan maksud penulis, (2) penerjemah harus memiliki keilmuan dan pengetahuan tentang kedua bahasa (bahasa sumber dan bahasa 
target), (3) menghindari penerjemahan kata per kata, (4) menggunakan bentuk-bentuk bahasa yang umum digunakan, (5) memilih kata yang tepat dalam menerjemahkan.

Selanjutnya hal yang harus diperhatikan dalam menerjemahkan teks adalah struktur kalimat bahasa sasaran yang baik dan benar. Jika tidak memperhatikan hal ini para penerjemah akan terjebak pada kesalahan-kesalahan seperti kesalahan gramatikal. Kesalahan-kesalahan berbahasa mungkin saja terjadi meskipun seseorang telah mempelajari bahasa asing selama beberapa waktu bahkan seseorang yang mempelajari bahasa sumbernya sendiri juga mungkin saja melakukan kesalahan ketika memproduksi bahasa. Menurut Brendensen (2011:2) terdapat tiga kategori kesalahan, yaitu mistake, yang terbagi lagi menjadi tiga jenis: (1) accidental, yaitu kesalahan yang dilakukan oleh pembelajar bahasa kedua yang sering terjadi karena kekeliruan pembelajar dan bisa diantisipasi, (2) stupid, yaitu kesalahan accidental yang diabaikan oleh pembelajar, (3) kesalahan yang sudah memasuki tataran kejahatan ilmiah (scientific crime). Brown (2007:263-266) juga mengungkapkan bahwa kesalahan dapat terjadi karena transfer antarbahasa yakni pemindahan unsur bahasa pertama yang telah memfosil ke dalam bahasa yang sedang dipelajari, transfer intrabahasa yakni pemindahan unsur bahasa pertama terhadap bahasa itu sendiri, kesalahan konteks pembelajaran, yaitu kesalahan yang disebabkan oleh metode, materi, cara mengajar dosen/guru yang salah, kesalahan karena strategi belajar bahasa yang dipelajari akibat dari pendekatan yang dilakukan pembelajar terhadap materi kaidah bahasa yang sedang dipelajari, dan kesalahan yang terjadi karena strategi komunikasi yaitu pendekatan yang dilakukan oleh pembelajar dalam berkomunikasi dengan orang lian/penutur asli.

Kesalahan gramatikal bisa terjadi dalam proses penerjemahan jika penerjemah atau seseorang yang berusaha menerjemahkan teks tidak memperhatikan tata bahasa sasaran. Dickins (2006:96) mengatakan bahwa dalam grammar yang difokuskan adalah tataran morfologi dan sintaksis. Menurut Chaer (2008:3) secara etimologi kata morfologi berasal dari kata morf yang berarti 'bentuk' dan logi yang berarti 'ilmu', jadi secara harafiah morfologi berarti ilmu mengenai bentuk. Ramlan (1987:25) mengungkapkan proses morfologis adalah proses pembentukan kata-kata dari satuan lain yang merupakan bentuk dasarnya. Sintaksis didefinisikan sebagai bagian dari studi linguistik yang mempelajari struktur kalimat (Fromkin, 1983:200). Richard (1985:285) juga menyebutkan bahwa sintaksis adalah studi tentang bagaimana kata-kata digabungkan untuk membentuk kalimat dan atiuran yang mengatur pembentukan kalimat. Unit sintaksis dari deskripsi gramatikal adalah morfem, kata, frase dan kalimat. Kata-kata dapat dikelompokkan ke dalam kelas kata. Sifat sintaksis kelas kata tercermin oleh cara khas di mana anggotanya berfungsi dalam kalimat dan frase. Kelas kata dibagi ke dalam kelas terbuka dan kelas tertutup. Kelas terbuka keanggotaannya tidak dibatasi dan keanggotaan kelas tanpa batas besar dan tertutup dibatasi karena mereka tidak mengizinkan penciptaan anggota baru. Dalam bahasa Inggris ada empat kelas kata utama, yaitu kata benda, kata sifat, kata kerja, dan kata keterangan. Kelas kata minor adalah preposisi, konjungsi, artikel, angka, kata ganti, quantifier, kata seru (Aarts, 1982:22). Dalam penerjemahan seringkali kelas kata minor mengalami pengabaian karena tidak semua kelas kata minor dalam bahasa Inggris terdapat juga dalam bahasa Indonesia contohnya preposisi atau kata depan. Bahasa Inggris memiliki berbagai macam preposisi atau kata depan yang mempunyai arti hampir sama sehingga terkadang terjadi kesalahan dalam menempatkan prepposisi yang tepat untuk kata tertentu, begitu juga dengan penggunaan artikel atau kata sandang. Terdapat tiga kata sandang dalam bahasa Inggris, yaitu $a$, an, dan the. Ketiganya memiliki arti dan fungsi masing-masing sehingga harus ditempatkan secara tepat dalam sebuah kalimat. Seringkali terjadi penghilangan ataupun penambahan kata yang tidak tepat dalam penerjemahan teks bahasa Indonesia ke bahasa Inggris karena kekurangpahaman penggunaan masing-masing kata atau kelas kata.

Kesalahan umum yang berkaitan dengan perubahan-perubahan struktur yang sering dilakukan adalah penghilangan (omission) adalah penghilangan unsur-unsur kalimat tertentu yang justru diperlukan, penambahan (addition) adalah penambahan 
unsur-unsur kalimat tertentu yang justru diperlukan, misformation adalah pembentukan unsur kalimat yang salah, dan misordering adalah penempatan unsur kalimat yang salah (Dulay, 1982: 59-63).

\section{METODE}

Metode dalam penelitian ini adalah deskriptif kualitatif. Penelitian ini bertujuan untuk mendeskripsikan fenomena kesalahan yang sering dilakukan oleh para mahasiswa ketika menerjemahkan teks abstrak ke dalam bahasa Inggris. Menurut pendapat Sukmadinata (2011: 73) penelitian deskripsi kualitatif ditujukan untuk mendeskripsikan dan menggambarkan fenomena-fenomena yang ada, baik bersifat alamiah maupun rekayasa manusia, yang lebih memperhatikan mengenai karakteristik, kualitas, dan keterkaitan antar kegiatan. Bogdan dan Taylor dalam Moleong (2011:4) juga mengungkapkan bahwa metode kualitatif merupakan prosedur penelitian yang menghasilkan data deskriptif berupa kata-kata tertulis atau lisan dari orang-orang dan perilaku yang diamati. Data yang dihasilkan berupa kata-kata, gambar serta perilaku manusia.

Subjek pada penelitian ini adalah para mahasiswa USM yang sedang menyelesaikan tugas akhir penulisan skripsi. Mereka berasal dari enam program studi yang berbeda. Peneliti mengambil dua sampai lima subjek di masing-masing program studi. Sedangkan objek dalam penelitian ini yaitu teks terjemahan abstrak (Indonesia-Inggris) untuk dianalisis kesalahan gramatikalnya. Sampel yang digunakan adalah sampel acak atau random sampling. Total sampel yang dijadikan objek penelitian berjumlah 30 teks abstrak. Jumlah kalimat dari 30 teks abstrak tersebut adalah 366 kalimat.

Teknik pengumpulan data menggunakan teknik pustaka, simak, dan catat. Dalam hal ini peneliti akan membaca teks abstrak terjemahan, mencermati, dan mencatat hal yang berkaitan dengan tujuan penelitian.

Masalah utama dalam penelitian ini adalah kesalahan gramatikal pada teks abstrak terjemahan dari bahasa Indonesia ke bahasa Inggris. Peneliti akan menganalisis kesalahan gramatikal yang secara umum sering dilakukan oleh para pembelajar bahasa, yaitu penghilangan (omission) adalah penghilangan unsur-unsur kalimat tertentu yang justru diperlukan, penambahan (addition) adalah penambahan unsur-unsur kalimat tertentu yang justru diperlukan, misformation adalah pembentukan unsur kalimat yang salah, dan misordering adalah penempatan unsur kalimat yang salah (Dulay, 1982: 59-63). Prosedur analisis data yang dilakukan melalui beberapa tahap: Pertama, peneliti membaca dan mencermati kalimat-kalimat pada teks abstrak sekaligus menandai jenis-jenis kesalahan yang terdapat pada teks tersebut, kedua, peneliti menggolongkan jenis-jenis kesalahan gramatikal, selanjutnya peneliti mencatat contoh-contoh kalimat yang secara gramatikal salah, setelah itu peneliti memdeskripsikan kesalahan gramatikal tersebut sekaligus membuat kalimat yang benar.

\section{HASIL DAN PEMBAHASAN}

Dari ketiga puluh abstrak yang mengandung 366 kalimat peneliti menemukan 24 jenis kesalahan yang terbagi menjadi penghilangan kata (omission), penambahan kata (addition), misformation adalah pembentukan unsur kalimat yang salah, dan misordering adalah penempatan unsur kalimat yang salah, juga terdapat jenis kesalahan yang lain yang tidak termasuk di empat kategori tersebut. Total kesalahan gramatikal yang dilakukan oleh para mahasiswa adalah sebanyak 547 kesalahan. Temuan penelitian ini dapat dilihat pada table berikut ini:

Tabel 1. Frekuensi Jenis Kesalahan Gramatikal

\begin{tabular}{|c|c|c|c|}
\hline \multirow[b]{2}{*}{$\begin{array}{l}\mathbf{N} \\
\mathbf{o}\end{array}$} & \multirow[b]{2}{*}{ Jenis kesalahan } & \multicolumn{2}{|c|}{ Frekuensi } \\
\hline & & $\Sigma$ & $\begin{array}{l}\text { Perse } \\
\text { n }\end{array}$ \\
\hline \multirow[t]{7}{*}{1} & $\begin{array}{l}\text { Penghilangan kata } \\
\text { (Omission) }\end{array}$ & & \\
\hline & a. Kata sandang (article) & $\begin{array}{l}18 \\
9\end{array}$ & 34,55 \\
\hline & b. Subjek (subject) & 11 & 2,01 \\
\hline & c. Kata kerja (Verb) & 9 & 1,65 \\
\hline & $\begin{array}{l}\text { d. Tanda baca } \\
\text { (punctuation) }\end{array}$ & 22 & 4,02 \\
\hline & $\begin{array}{l}\text { e. Tunggal/Jamak } \\
\text { (singular/plural) }\end{array}$ & 10 & 1,83 \\
\hline & $\begin{array}{l}\text { f. Kata depan } \\
\text { (preposition) }\end{array}$ & 33 & 6,03 \\
\hline 2 & \multicolumn{3}{|l|}{ Penambahan kata } \\
\hline
\end{tabular}


Dinamika Sosial Budaya, Vol 22, No. 1, Juni 2020, pp 54-64

p-ISSN: 1410-9859\& e-ISSN: 2580-8524

http://journals.usm.ac.id/index.php/jdsb

\begin{tabular}{|c|c|c|c|}
\hline \multirow{2}{*}{$\begin{array}{l}\mathbf{N} \\
\mathbf{0}\end{array}$} & \multirow[b]{2}{*}{ Jenis kesalahan } & \multicolumn{2}{|c|}{ Frekuensi } \\
\hline & & $\Sigma$ & $\begin{array}{l}\text { Perse } \\
\text { n }\end{array}$ \\
\hline & \multicolumn{3}{|l|}{ (Addition) } \\
\hline & a. Kata sandang (article) & 20 & 3,66 \\
\hline & b. Subjek (subject) & 5 & 0,91 \\
\hline & c. Kata kerja (Verb) & 7 & 1,28 \\
\hline & d. To-infinitive & 2 & 0,37 \\
\hline & $\begin{array}{l}\text { e. Kata depan } \\
\text { (preposition) }\end{array}$ & 4 & 0,73 \\
\hline & $\begin{array}{l}\text { f. Tanda baca } \\
\text { (punctuation) }\end{array}$ & 8 & 1,46 \\
\hline \multirow[t]{5}{*}{3} & \multicolumn{3}{|l|}{$\begin{array}{l}\text { Pembentukan unsur } \\
\text { kalimat yang salah } \\
\text { (Misformation) }\end{array}$} \\
\hline & $\begin{array}{l}\text { a. Pembentukan Kata } \\
\text { depan (preposition) }\end{array}$ & 10 & 1,83 \\
\hline & $\begin{array}{l}\text { b. Pembentukan Kata } \\
\text { kerja (verb) }\end{array}$ & 12 & 2,19 \\
\hline & $\begin{array}{l}\text { c. Pembentukan Kata } \\
\text { keterangan }(a d v e r b)\end{array}$ & 7 & 1,28 \\
\hline & $\begin{array}{l}\text { d. Pemilihan Kata depan } \\
\text { (preposition) }\end{array}$ & 21 & 3,84 \\
\hline \multirow[t]{3}{*}{4} & \multicolumn{3}{|l|}{$\begin{array}{l}\text { Penempatan unsur } \\
\text { kalimat yang salah } \\
\text { (Misordering) }\end{array}$} \\
\hline & a. Kata benda (noun) & 11 & 2,01 \\
\hline & $\begin{array}{l}\text { b. Kata keterangan } \\
\text { (adverb) }\end{array}$ & 3 & 0,55 \\
\hline \multirow[t]{9}{*}{5} & \multicolumn{3}{|l|}{$\begin{array}{l}\text { Jenis kesalahan yang lain } \\
\text { (Other errors) }\end{array}$} \\
\hline & a. Tense & 5 & 0,91 \\
\hline & $\begin{array}{l}\text { b. Bentuk kalimat pasif } \\
\text { (passive voice) }\end{array}$ & 8 & 1,46 \\
\hline & $\begin{array}{l}\text { c. Pemilihan kata (word } \\
\text { choice) }\end{array}$ & 10 & 1,83 \\
\hline & $\begin{array}{l}\text { d. Penggabungan kalimat } \\
\text { (run-on sentence) }\end{array}$ & 23 & 4,20 \\
\hline & $\begin{array}{l}\text { e. Kesalahan ejaan } \\
\text { (misspelling) }\end{array}$ & 17 & 3,11 \\
\hline & f. $S$-V Agreement & 63 & 11,52 \\
\hline & $\begin{array}{l}\text { g. Kalimat yang tidak } \\
\text { lengkap (fragment) }\end{array}$ & 37 & 6,76 \\
\hline & Total kesalahan & $\begin{array}{l}54 \\
7\end{array}$ & $\begin{array}{l}100,0 \\
0\end{array}$ \\
\hline
\end{tabular}

\section{Penghilangan kata (Omission)}

\section{a. Kata sandang (article)}

Salah : The method used in this study is descriptive qualitative method by conducting interview, observation and documentation.

Benar : The method used in this study is $\underline{a}$ descriptive qualitative method by conducting interview, observation, and documentation.

Kata sandang diperlukan dalam frasa descriptive qualitative karena frasa tersebut pertama disebutkan, jika baru pertama kali disebutkan maka dibutuhkan kata sandang ' $a$ ' atau 'an', yaitu kata sandang tak tentu (indefinite article). Kata sandang ' $\mathrm{a}$ ' menunjukkan bentuk kata benda tunggal dengan pelafalan bunyi konsonan.

\section{b. Subjek (subject)}

Salah : With oversight and control programs as well as a good working system will get a good home-based products are free from danger and unfit for consumption.

Benar : With oversight and control programs as well as a good working system the tofu producer will get good homebased products which are harmless and fit for consumption.

Unsur yang hilang dalam kalimat di atas adalah subjek. Subjek merupakan unsur yang penting dalam pembentukan kalimat karena syarat utama terbentuknya kalimat dalam bahasa Inggris adalah adanya minimal satu subjek dan satu kata kerja. Kalimat yang tidak mempunyai subjek tidak bisa dikatakan sebagai kalimat, hanya kumpulan frasa saja. Oleh karena itu, perlu adanya penambahan subjek dalam kalimat tersebut.

\section{c. Kata kerja (Verb)}

Salah : Planning the top structure using SAP 2000 version 14, while the bottom structure is planned manually.

Benar : Planning the top structure uses SAP 2000 version 14, while the bottom structure is planned manually.

Sama seperti penjelasan pada poin $b$, kalimat yang terdapat pada poin $\mathrm{c}$ ini tidak memiliki kata kerja sehingga rangkaian kata- 
kata tersebut tidak bisa dikatakan sebagai kalimat karena unsur utama pembentuk kalimatnya tidak ada, yaitu kata kerja. Oleh karena itu, kata using harus diganti menjadi kata uses supaya terbentuk kalimat yang benar.

\section{d. Tanda baca (punctuation)}

Salah : The method used in this study is descriptive qualitative method by conducting interview, observation and documentation.

Benar : The method used in this study is a descriptive qualitative method by conducting interview, observation, and documentation.

Tanda baca juga memiliki peranan penting dalam sebuah kalimat atau paragraph. Jika pengunaan tanda baca tidak diperhatikan sering kali akan menimbulkan kesalahan seperti salah tafsir. Pada rangkaian kata yang berseri, tiga kata atau lebih, tanda baca koma harus memisahkan tiap kata yang berseri tersebut.

\section{e. Tunggal/Jamak (singular/plural)}

Salah : In connotation there are five communication code, the hermeneutic code, the proairetic code, the cultural code, code of semik and symbolic code.

Benar : In the connotation, there are five communication codes, namely the hermeneutics codes, proairetic codes, cultural codes, semic codes, and symbolic codes.

Dalam bahasa Inggris jumlah kata benda diperhitungkan baik itu tunggal maupun jamak. Sudah tertulis dalam aturan bahwa kata benda yang jamak harus diberi huruf ' $s$ ' di akhir kata benda tersebut. Unsure yang hilang dalam frasa five communication code adalah penanda jamak. Oleh karena itu pembetulannya adalah five communication codes.

\section{f. Kata depan (preposition)}

Salah : The study will analyze the legal consequences of selling the estate without the consent of the rest heirs by the Code - the Civil Code, because in the process of engagement buying and selling land, especially land inheritance, should be the one engagement are in the know and approved by all the rightful heir inherited the land.

Benar : The study will analyze the legal consequences of selling the estate without the consent of the beneficiaries by the Code - the Civil Code because the process of buying and selling land, especially the land of inheritance, should be the engagement known and approved by all the beneficiaries who inherited the land.

Penggunaan kata depan dalam bahasa Inggris juga tidak dapat diabaikan. Kata depan atau preposisi ini menunjukkan ubungan antara object of preposition dengan elemen kata yang lain di dalam suatu kalimat. Object of preposition dapat berupa kata benda, kata ganti, atau klausa kata benda. Contoh kalimat yang salah tersebut kehilangan unsure kata depan of. Kata of seharusnya muncul untuk memperjelas objek dari kata land yaitu inheritance sehingga yang benar adalah the land of heritance.

\section{Penambahan kata (Addition)}

\section{a. Kata sandang (article)}

Salah : With oversight and control programs as well as a good working system will get a good home-based products are free from danger and unfit for consumption.

Benar : With oversight and control programs as well as a good working system the tofu producer will get good homebased products which are harmless and fit for consumption.

Kata sandang $a$ tidak diperlukan dalam kalimat tersebut karena penggunaannya tidak sesuai. Kata sandang $a$ harus digunakan untuk menandai kata benda yang tunggal. Hal ini tidak sesuai jika frasanya adalah a good homebased products karena kata benda products dituliskan dalam bentuk jamak. Oleh karena itu kata sandang $a$ seharusnya tidak digunakan dalam kalimat tersebut. 


\section{b. Subjek (subject)}

Salah : Research it is based on by the presence of a phenomenon business of being endured by $C V$. Harly Jaya.

Benar : Research is based on by the presence of a phenomenon business of being endured by $C V$. Harly Jaya.

Terdapat dua subject dalam kalimat tersebut, yakni kata research dan it. Keduanya bisa menjadi subjek dalam kalimat. Oleh karena itu terdapat unsur penambahan kata yang tidak diperlukan. Untuk memperbaikinya kata it harus dihilangkan supaya tatanan kalimatnya sesuai dengan struktur gramatikal yang benar.

\section{c. Kata kerja (Verb)}

Salah : The number of domestic industries that manufacture using simple technology makes production has decent short compared with the consumption of food products processed by high-tech.

Benar : The number of domestic industries that manufacture using simple technology making production declined shortly compared to the consumption of food products processed with high technology.

Tidak boleh ada kata kerja ganda dalam satu kalimat sederhana, aturannya adalah ada satu subjek dan satu kata kerja dalam kalimat yang sederhana. Kalimat yang salah tersebut mengandung dua kata kerja, yaitu makes dan has. Oleh karena itu salah satunya harus diubah menjadi bentuk kata sifat supaya kalimatnya menjadi benar.

\section{d. Kata depan (preposition)}

Salah : Such approval must be by written evidence has the force of law so that in the event of a dispute may be used as evidence in court.

Benar : Such approval must be written evidence has the force of law so that in the event of a dispute may be used as evidence in court.

Penulisan kata depan by menjadi unsur tambahan yang salah atau tidak diperlukan dalam kalimat tersebut. Struktur kalimat pasif seperti pada kalimat di poin d ini, modal $+b e$, harus langsung diikuti oleh bentuk kata kerja ketiga atau past participle. Penulisan by sangat tidak diperlukan pada struktur kalimat di atas.

\section{e. To-infinitive}

Salah : To obtain the nutritional value close to SNI 01-7111.1-2005 and the panelist's preference level on the organoleptic test is on F1 formulation.

Benar : The nutritional value close to SNI 01-7111.1-2005 and the panelist's preference level on the organoleptic test is on F1 formulation.

To-infinitive dalam kalimat tersebut tidak diperlukan karena kehadirannya membuat subjek dalam kalimat tersebut tidak jelas. Bentuk to-infinitive bisa menjadi subjek asalkan langsung diikuti oleh kata kerja, biasanya bentuk kalimat ini adalah klausa kata benda.

\section{f. Tanda baca (punctuation)}

Salah : This study examines factors such as: auditor independence, audit quality, institutional ownership ....

Benar : This study examines factors such as auditor independence, audit quality, institutional ownership ....

Penulisan tanda baca titik dua setelah kata such as tidak diperlukan, oleh karena itu harus dihapus saja. Walaupun menjelaskan contoh-contoh dari sebuah faktor tertentu tanda baca tersebut tidak diperlukan.

\section{Pembentukan unsur kalimat yang salah (Misformation)}

\section{a. Pembentukan kata depan (preposition)}

Salah : This study aims to determine the effect influence of the difference of the length of time the heating on the antioxidant properties of antioxidant white tea extracts.

Benar : This study aims to determine the effect influence of the difference in the length of time the heating on the antioxidant properties of antioxidant white tea extracts. 
Bentuk difference in digunakan untuk membandingkan atau membedakan dua hal sehingga tepat digunakan pada kalimat tersebut karena dalam kalimat tersebut yang dibedakan adalah ekstrak antioksidan pada teh biasa dan ekstrak antioksidan pada the putih.

\section{b. Pembentukan kata kerja (verb)}

Salah : The purposed of this study was to find out the differences of self control between students who memorize the Qur'an and students who do not memorize The Qur'an.

Benar : The purpose of this study was to find out the differences of self control between students who memorize the Qur'an and students who do not memorize The Qur'an.

Kata yang tepat digunakan untuk kalimat tersebut adalah kata benda karena kata benda purpose akan membentuk subjek. Subjek terbentuk dari kata benda atau kata ganti dalam struktur gramatkal bahasa Inggris. Oleh karena itu bentuk kata kerja purposed tidak tepat dijadikan sebagai subjek.

\section{c. Pembentukan kata keterangan (adverb)}

Salah : This research purposely to know the influence of he composition of kepok banana flour and red bean flour with different percentage of physicochemical and organoleptic test.

Benar : This research purposes to know the influence of the composition of pisang kepokflour and red bean flour with different percentages of physicochemical and organoleptic test.

Bentuk kata yang tepat pada kalimat tersebut adalah kata kerja untuk melengkapi subjek the research. Ketika menggunakan bentuk kata keterangan yaitu purposely kalimat tersebut menjadi tidak lengkap karena tidak mempunyai kata kerja.

\section{d. Pemilihan kata depan (preposition)}

Salah : The data obtained were analyzed for variety and if there were differences between treatments then tested further by double Duncan region test (DMRT) at $5 \%$ level.

Benar : The data obtained were analyzed for variety and if there were differences among treatments then further tests were needed by the double Duncan region test (DMRT) at a $5 \%$ level.

Kata between dan among mempunyai arti yang sama ketika diterjemahkan ke dalam bahasa Indonesia. Namun, ketika menggunakan kata ini dalam bahasa Inggris harus memperhatikan jumlah kata benda yang dijelaskan. Between digunakan ketika membandingkan dua hal saja dan diikuti dengan kata sambung and, sedangkan among digunakan untuk membandingkan lebih dari dua hal. Oleh karena itu kata yang cocok untuk dipakai pada kalimat tersebut adalah among karena treatments merujuk pada lebih dari dua hal.

\section{Penempatan unsur kalimat yang salah (misordering)}

\section{a. Penempatan kata benda (noun)}

Salah : Data analysis was performed using $\underline{a}$ model inner and outer models with PLS 3.0 program.

Benar : Data analysis was performed using an inner model and outer models with PLS 3.0 program.

Kata benda dalam bahasa Inggris bisa diterangkan oleh kata sifat atau kata sifat memberi keterangan pada kata benda yang melekat. Posisi kata sifat diletakkan sebelum kata benda. Oleh karena itu frasa a model inner tidak tepat, seharusnya adalah an inner model. Kata inner memberi sifat pada kata model sehingga kemudian kata sandang yang mengikuti mennjadi an karena pelafalan kata inner diawali dengan huruf vokal.

\section{b. Penempatan kata keterangan (adverb)}

Salah : The results of this study indicate that simultaneously the variables auditor independence, audit quality, institutional ownership, managerial ownership, audit committee, independent commissioner, firm size 
and leverage affect the integrity of financial statements.

Benar : The results of this study indicate that the variables auditor independence, audit quality, institutional ownership, managerial ownership, audit committee, independent commissioner, firm size, and leverage simultaneously affect the integrity of the financial statements.

Kata keterangan bisa diletakkan di awal kalimat, di tengah-tengah, maupun di akhir kalimat pada kalimat bahasa Inggris. Tetapi penempatan kata keterangan tersebut juga harus diperhatikan karena terkadang bisa membuat kalimat menjadi rancu atau ambigu. Kata keterangan pada kalimat tersebut lebih tepatnya diletakkan berdampingan dengan kata kerjanya karena fungsi kata keterangan pada kalimat tersebut menerangkan kata kerja.

\section{Jenis kesalahan yang lain (other errors)}

\section{a. Tense}

Salah : The effectiveness of the average motor vehicle tax revenue from January - September 2018 is $49.01 \%$

Benar : The effectiveness of the average motor vehicle tax revenue from January - September 2018 was $49.01 \% \ldots$.

Tense dalam bahasa Inggris berperan penting untuk menunjukkan waktu atau kapan kejadian berlangsung, apakah hari ini, kemarin, atau nanti. Pada kalimat tersebut tense atau bentuk waktu yang digunakan tidak tepat yaitu menggunakan is. Hal ini tidak sesuai dengan kata keterangan yang menunjukkan tahun dan bulan yang spesifik. Oleh karena itu, bentuk tense yang tepat adalah past tense atau bentuk lampau karena kejadiannya sudah berlalu sehingga kata kerja yang digunakan adalah kata kerja bentuk kedua, was.

\section{b. Bentuk kalimat pasif (Passive voice)}

Salah : Tests performed twice as a comparison.

Benar : Tests were performed twice as a comparison.
Bentuk kalimat aktif pada kalimat tersebut kurang tepat karena subjek pada kalimat tersebut tidak diketahui, yaitu orang yang melakukan tes. Oleh karena itu bentuk kalimat yang tepat adalah menggunakan kalimat pasif. Pada kalimat pasif tersirat makna tes dilakukan oleh seseorang namun siapakah seseorang itu tidak terlalu dihiraukan. Apabila pelaku atau agent dirasa penting untuk disertakan maka bisa dituliskan tests were performed twice by the researcher as a comparison.

\section{c. Pemilihan kata (Word choice)}

Salah : Data that are obtained $\underline{i s}$ analyzed using analysis of variety ....

Benar : Data obtained were analyzed using analysis of variance.....

Kata variety dan variance memang mempunyai kelas kata yang sama, yaitu kata benda. Namun meskipun begitu kata tersebut tidak dapat digunakan secara bergantian karena mempunyai makna yang sedikit berbeda. Variety mengandung makna yang bervariasi dan berubah-ubah, sedangkan variance mempunyai makna adanya dua hal atau lebih yang berbeda. Pada konteks kalimat tersebut kata yang tepat adalah variance karena penulis menerapkan analisis data yang berbeda-beda.

\section{d. Penggabungan kalimat (Run-on sentence)}

Salah : To mark the progress of a country is the implementation of information systems. No exception of Indonesia, which should not ignore the development of information.

Benar : To mark the progress of a country is the implementation of information systems, including, Indonesia should not ignore the development of information.

Penggabungan kalimat di bahasa Inggris harus tepat sehingga membentuk kalimat majemuk atau kalimat majemuk bertingkat yang tepat. Kalimat tersebut mengadopsi bentuk atau struktur kalimat 
bahasa Indonesia. Kalimat kedua pada kalimat di atas tidak memiliki elemen kalimat yang utama yaitu tidak adanya subjek dan kata kerja sehingga tidak dapat dikatakan sebagai kalimat namun hanya frasa. Untuk memperbaikinya penggabungannya harus tepat dan harus menghilangkan beberapa kata.

\section{e. Kesalahan ejaan (Misspelling)}

Salah : This research was carried out at the chemical laboratory Semarang University, Soegijapranata universty ....

Benar : This research was carried out at the chemical laboratory Semarang University, Soegijapranata University ....

Kesalahan eja juga menjadi salah satu kesalahan gramatikal yang dilakukan oleh pembelajar bahasa terutama jika mereka menerjemahkan kata serapan yang ada di bahasa sumber maupun bahasa target. Seringkali hal ini tidak menjadi perhatian hanya karena pelafalannya hampir sama misalnya. Penggunaan huruf capital juga harus sesuai dengan kaidah yang benar seperti pada kata university tersebut harus menggunakan huruf kapital karena melekat pada sebuah nama universitas.

\section{f. Kesesuaian antara subjek dan kata kerja (S-V Agreement)}

Salah : This study conclude that there $\underline{\text { is }}$ self control differences between students who memorize the Quran and students who do not memorize the Al'Quran.

$\begin{aligned} & \text { Benar : } \text { This study concludes that } \\ & \text { there are self-control differences } \\ & \text { between the students who memorize } \\ & \text { the Quran and the students who do } \\ & \text { not memorize the Quran. }\end{aligned}$

Kesesuaian antara subjek dan kata kerja dalam bahasa Inggris menjadi hal yang penting karena jumlah kata benda baik tunggal maupun jamak diperhitungkan. Subjek yang tunggal harus berpasangan dengan kata kerja yang tunggal juga, berarti harus ada tambahan 's' dibelakang kata kerja utama. Sebaliknya subjek yang jamak juga harus berpasangan dengan kata kerja yang jamak pula. Hal ini yang sering diabaikan oleh para pembelajar bahasa Inggris. Seringkali tidak memperhitungkan kesesuaian antara subjek dan kata kerja karena tatanan struktur bahasa yang dianggap sama.

\section{g. Kalimat yang tidak lengkap (fragment)}

$\begin{aligned} & \text { Salah : } \begin{array}{l}\text { The research sample of } 100 \\ \text { respondents using purposive- } \\ \text { sampling. }\end{array} \\ & \text { Benar }: \begin{array}{l}\text { The research sample of } 100 \\ \text { respondents used purposive- } \\ \text { sampling. }\end{array}\end{aligned}$

Kalimat tersebut tergolong kalimat yang tidak lengkap karena tidak mempunyai kata kerja. Seringkali bentuk $V$-ing atau kata kerja bentuk -ing dianggap sebagai kata kerja, padahal sebenarnya bukan. Bentuk $V$-ing menjadi kata kerja ketika ada to be. Oleh karena itu kata using diganti dengan used sebagai kata kerja.

\section{KESIMPULAN}

Kesalahan gramatikal yang seringkali terjadi pada teks abstrak terjemahan mahasiswa adalah kesalahan penggunaan kata sandang (article), kesesuaian antara subjek dan kata kerja dalam kalimat (subject-verb agreement), dan pembentukan kalimat yang tidak lengkap (sentence fragment). Kesalahankesalahan tersebut terjadi karena adanya perbedaan struktur kalimat dari bahasa sumber ke bahasa sasaran. Penggunaan kata sandang dalam bahasa Inggris adalah hal yang penting namun karena kekurangpahaman dalam menggunakan kata sandang tersenut menjadi batu sandungan bagi para pembelajar bahasa atau para penerjemah amatir. Kesesuaian antara subjek dan kata kerja juga merupakan hal yang penting karena jumlah nomina dalam bahasa Inggris diperhitungkan dan bentuk kata kerja yang mengikuti juga akan berbeda. Konsep ini juga tidak terdapat di bahasa Indonesia sehingga aturan seringkali dilupakan. Pembentukan kalimat yang tidak lengkap terjadi karena proses penerjemahan yang mengadopsi tata bahasa bahasa sumber sehingga seringkali ditemukan kalimat yang tidak mempunyai subjek atau kata kerja, maupun rangkaian kata yang dianggap kalimat 
Dinamika Sosial Budaya, Vol 22, No. 1, Juni 2020, pp 54-64

p-ISSN: 1410-9859\& e-ISSN: 2580-8524

http://journals.usm.ac.id/index.php/jdsb

namun justru hanya rangkaian frasa yang tidak membentuk kalimat sama sekali. Hal ini terjadi karena penerjemahan yang dilakukan secara literal saja dengan mengadopsi tata bahasa sumber. Dari penjelasan tersebut dapat disimpulkan bahwa kegiatan menerjemahkan bukan hanya sekedar mengubah bahasa sumber ke dalam bahasa sasaran. Mahasiswa yang membuat abstrak seringkali menerjemahkan abstraknya dari bahasa Indonesia ke bahasa Inggris secara literal tanpa memperhatikan kaidah struktur gramatikal bahasa Inggris dengan tepat, sehingga kesalahan-kesalahan gramatikal pasti terjadi dan diabaikan oleh mahasiswa.

\section{Saran}

Dalam membuat abstrak walaupun prosesnya adalah menerjemahkan dari tulisan bahasa Indonesia ke bahasa Inggris, mahasiswa hendaknya memperhatikan susunan kalimat bahasa Inggris yang menjadi bahasa sasaran, karena aturan dalam pembentukan kalimatnya sudah pasti berbeda dengan bahasa Inggris. Ada aturan-aturan yang harus diperhatikan oleh para mahasiswa ketika membuat abstrak atau karangan dalam bahasa Inggris, misalnya penggunaan kata benda yang jamak dan tunggal, subjek yang harus sesuai dengan kata kerja yang dipakai dengan memperhatikan jumlah subjek tersebut, kala (tense) yang juga harus diperhatikan karena berhubungan dengan konsep waktu sekarang, saat ini, atau kemarin. Janganlah sekedar menerjemahkan bebas tanpa memperhatikan aturan gramatikal bahasa sasaran karena bagaimanapun juga sebuah tulisan merupakan sarana penyampaian pesan kepada pembaca yang harus dituliskan secara baik, benar, dan jelas sehingga pesan yang terkandung di dalamnya dapat tersampaikan dengan baik.

\section{DAFTAR PUSTAKA}

Aarts, Flor and Aarts, J. 1982. English Syntatic Structure. London: Oxford Pergamon Press.

Bassnet, Susan. 2005. Translation Studies Third Edition. London: Routledge.

Catford, J.C. 1965. A Linguistic Theory of Translation. Oxford: Oxford University Press.
Chaer, Abdul. 2003. Linguistik Umum. Jakarta: Rineka Cipta.

Dickins, James, Sandor Hervey, Ian Higgins. 2006. Thinking Arabic Translation: A Course in Translation Method. New York: Routledge.

Douglas, H. Brown. 2007. Principle of Language Learning and Teaching. San Fransisco: Pearson Education.

Dulay, H. and S. Krashen. 1982. Language Two. New York: Oxford University Press.

Fromkin, Victoria and R. Rodman. 1983. An Introduction to Language. Boston: Wardsworth.

Hatim, Basil dan Munday, Jeremy. 2004. Translation: An Advance Resource Book. London and New York: Routledge.

Herman, J. Brendenson. 2011. A Student's Guide to Data and Error Analysis. Cambridge: Cambridge Univ Press.

Nababan, M. Rudolf. 2003. Aspek Teori Penerjemahan dan Pengalihbahasaan. Surakarta: UNS Press.

Ramlan. 1987. Morfologi: Suatu Tinjauan Deskriptif. Yogyakarta: C.V. Karyono.

Richard, Jack. 1985. Syntax. Cambridge: Cambridge Univ Press.

Sukmadinata, Nana Syaodih. 2011. Metode Penelitian Pendidikan. Bandung: Rosdakarya.

Suryawinata, Zuchridin dan Sugeng Haryanto. 1989. Translation: Bahasan Teori dan Penuntun Praktis Penerjemah. Yogyakarta: Kanisius. 
Dinamika Sosial Budaya, Vol 22, No. 1, Juni 2020, pp 54-64

p-ISSN: 1410-9859\& e-ISSN: 2580-8524

http://journals.usm.ac.id/index.php/jdsb 